\title{
Municipal eldercare: leadership differences in nursing homes and home help services
}

\begin{abstract}
Eldercare organizations have become increasingly multifaceted, and leaders play an important role in such organizations. This study used the developmental leadership questionnaire (DLQ) to compare perceptions of leadership in nursing homes with perceptions of leadership in home help services for older adults. A total of 21 leaders and 95 subordinates responded. Almost all were women; only seven men participated. Both leaders and subordinates perceived more positive leadership styles in nursing homes than in home help services. Leaders self-evaluations showed significant differences in the variables "promoting creativity" $(\mathrm{p}=0.021)$, "management-related competencies" ( $\mathrm{p}=0.022)$, "capacity to cope with stress" $(\mathrm{p}=0.002)$, and "results of leadership" ( $p=0.034)$. Evaluations of leaders by subordinates showed significant differences in "not overcontrolling" $(\mathrm{p}=0.018)$, and "social competence" $(\mathrm{p}=0.001)$. Our findings suggest that the social service should recognize the differences in the way nursing homes and home help services are organized and should recruit leaders with traits and behaviours desirable to each setting.
\end{abstract}

Keywords: Leadership, subordinates eldercare, nursing homes, home help services
Volume I Issue 2 - 2017

\author{
Dan Lundgren, ${ }^{1,2}$ Marie Ernsth Bravell,' \\ Ingemar Kåreholt $\mathrm{t}^{1,3}$ \\ 'Institute of Gerontology, School of Health and Welfare, Aging \\ Research Network - Jönköping (ARN-J), Jönköping University, \\ Sweden \\ ${ }^{2}$ Department of Analysis and Strategy, Division of Social \\ Services, Municipality of Jönköping, Sweden \\ ${ }^{3}$ Aging Research Centre, Karolinska Institute and Stockholm \\ University, Sweden
}

Correspondence: Dan Lundgren Institute of Gerontology, School of Health and Welfare, Jönköping University, Box 1026, SE-55I II Jönköping Sweden, Tel+ 4636 I0 24 80, Fax + 4636 10 II 80, Email dan.lundgren@ju.se

Received: November 04, 2016 | Published: March 22, 2017

\section{Introduction}

In recent decades, economic, ideological, social, and technological forces have had major impacts on social care. , $^{1,2}$ Health and social care managers in the public sector have had to cope with more explicit requirements for efficiency and quality at low cost and often have been criticized for not meeting expectations in a cost-effective manner ${ }^{3}$ National Board of Health and Welfare, $2006 .{ }^{4}$

Municipal social services provide eldercare in nursing homes and through home help services. The organizational structures of these two types of services are similar, but there are differences in the physical circumstances in which the services are provided. ${ }^{5}$ The physical distance between leaders and subordinates are large in home help services and small in nursing homes. This means that home help services are characterized by indirect leadership and nursing homes by direct leadership. ${ }^{6}$

Municipal home help workers provide services to older adults in their own homes, often to make it easier for individuals to continue to live there. ${ }^{7}$ Nursing home staffs provide social services and care for people who have more problems with activities of daily living (ADL) and more disabilities. ${ }^{8}$ Nursing home staffs work together in one building with direct leadership, e.g. with less physical distance to their leader. Home help workers, on the other hand, work alone in large geographic areas, therefore with indirect leadership and a more physical distance between leaders and subordinates. These fundamental environmental differences are supposed impact opportunities to engage in management and leadership: we assume that nursing home staff members have better opportunities to interact with leaders and colleagues, whereas home help staff members have limited opportunities to interact with leaders and colleagues. ${ }^{9,10}$

Some previous studies on leadership in eldercare have focused on leadership at a general level. Others have focused on leadership in either nursing homes or home help services but not both. More attention needs to be devoted to the wider organizational perspective; that is, to leadership in both nursing homes and home help services. It is important to increase the understanding of leadership in eldercare by studying differences in leadership in nursing homes and home help services. Such a study will improve our understanding of how these two organizational forms (nursing homes and home help services) affect leadership.

\section{The developmental leadership model}

The developmental leadership model is a version of the transformational leadership model, ${ }^{11,12}$ adapted to Swedish management culture. ${ }^{13,14}$ According to ${ }^{15}$ the transformational leadership model has a leading position and worldwide empirical support. There is one important difference between transformational leadership and developmental leadership is the use of the concept charisma. In Swedish management culture, charisma is associated with mixed feelings. In Sweden, charisma is often associated with people (e.g., Adolf Hitler or Joseph Stalin) who clearly had charisma, but this kind of leadership is not desirable in a modern leadership model, ${ }^{15}$

The developmental leadership model describes three leadership styles: developmental leadership, conventional leadership, and nonleadership. The developmental leadership is favoured and leads to better organizational outcomes and better individual development. ${ }^{15,16}$

Developmental leadership is based on three main factors: leader characteristics, contextual characteristics, and leadership styles. There are two main leader characteristics: basic prerequisites and desirable competencies. Basic prerequisites are factors related to the leader's personality. These are essential to the development of desirable competencies. Desirable competencies are valuable because they make it possible for people to engage in, developmental leadership. ${ }^{17}$ A combination of good basic prerequisites and desirable competencies is necessary, but not sufficient, for successful leadership, which is also affected by context. Contextual characteristics can be characteristics of the environment, organization, and group. All these characteristics can affect an organization and its leaders. ${ }^{14,17,13,18}$ For example,${ }^{19}$ note that organizations' structural characteristics influence how leaders 
engage in different behaviours. Leadership style is the last of the three main factors that ${ }^{13}$ identifies as important for successful leadership.

\section{Focus of this study}

A better understanding of how leadership works in different settings is essential for finding leadership characteristics that are adapted to the two eldercare settings (nursing homes and home help services). Leadership studies (e.g. regarding transformational leadership) have demonstrated several positive outcomes for the psychosocial working conditions in social care. ${ }^{20-22}$

This paper aims to analyse leaders' and subordinates' assessment of leadership behaviour and leader characteristics in nursing homes and home help services. It seeks to enhance knowledge about how leadership differ between nursing homes and home help services and to clarify leadership needs adapted to these settings. The study was designed to examine perceptions of leadership in nursing homes and home help services using the Developmental Leadership Questionnaire (DLQ).

\section{The specific research objectives that are analysed}

Leaders' assessment of their own leadership behaviour and leader characteristics in nursing homes and home help services;Subordinates' assessment of leadership behaviour and leader characteristics of their own leaders in nursing homes and home help services.

\section{Materials and methods}

\section{Participants and procedures}

This study had a cross-sectional design. 12 leaders in nursing homes and 12 in home help services were randomly selected from a municipality in southern Sweden. Each leader gave a questionnaire to five subordinates. Thus, the total sample was 24 leaders and 120 subordinates. A total of 21 of 24 leader questionnaires (88\%) were returned, 11 from nursing homes and 10 from home help service units, and a total of 95 of 120 subordinate questionnaires (79\%) were returned, 49 from nursing homes and 46 from home help services. The total response rate was $81 \%$. Leaders rated their own leadership on the Developmental Leadership Questionnaire (DLQ) (see below), and the subordinates rated their leaders. Every leader and subordinate returned the questionnaire to the process manager at the municipality's social service developmental unit in a prepaid envelope. All participants responded anonymously. The number of respondent from each care unit was at most five. For ethical reasons each questionnaire could not be connected to a specific nursing home or home help service unit. In addition to the DLQ questions, the questionnaire asked for the age, sex, eldercare setting (nursing homes or home help services) and for each leader number of subordinates. (Table 1) describes the respondents in terms of sex, age, level of education, and number of subordinates.

Table I Description of the respondents

\begin{tabular}{|c|c|c|c|c|c|c|}
\hline & \multicolumn{2}{|c|}{ Nursing home } & \multicolumn{2}{|c|}{ Home help services } & \multicolumn{2}{|l|}{ Total } \\
\hline & Leaders & Subordinates & Leaders & Subordinates & Leaders & Subordinates \\
\hline & $(n=I I)$ & $(n=49)$ & $(n=10)$ & $(n=46)$ & $(N=21)$ & $(N=95)$ \\
\hline \multicolumn{7}{|l|}{ Sex } \\
\hline Men & 2 & 2 & I & 2 & 3 & 4 \\
\hline Women & 8 & 45 & 9 & 41 & 17 & 86 \\
\hline Missing & 1 & 2 & - & 3 & 1 & 5 \\
\hline \multicolumn{7}{|l|}{ Age } \\
\hline$<30$ years & 1 & 3 & 2 & 6 & 3 & 9 \\
\hline $30-50$ years & 4 & 25 & 6 & 27 & 10 & 52 \\
\hline$>50$ years & 5 & 18 & 2 & 13 & 7 & 31 \\
\hline Missing & 1 & 3 & - & - & 1 & 3 \\
\hline \multicolumn{7}{|l|}{ Educational level } \\
\hline Compulsory & - & 9 & - & 6 & - & 15 \\
\hline Upper secondary & - & 37 & - & 26 & - & 63 \\
\hline University & 10 & - & 10 & 11 & 20 & 11 \\
\hline Missing & 1 & 3 & - & 3 & 1 & 6 \\
\hline \multicolumn{7}{|c|}{ Subordinates (leaders) } \\
\hline$<26$ & - & & - & & - & \\
\hline $26-35$ & 3 & & 4 & & 7 & \\
\hline $36-45$ & 4 & & 5 & & 9 & \\
\hline $46-55$ & 3 & & 1 & & 4 & \\
\hline$>55$ & I & & - & & I & \\
\hline
\end{tabular}




\section{Measures and questionnaire}

\section{Developmental leadership questionnaire (DLQ)}

We used developmental leadership questionnaire (DLQ) that includes 65 questions/items (Larsson et al., 2003) to measure leadership behaviour in eldercare. The instrument measures the three leadership styles: developmental leadership, conventional leadership, and non-leadership. To measure leadership characteristics, the questionnaire also included questions about desirable competencies.

For each item, the respondents were asked to assess how frequently the rated individual engaged in a specific behaviour. Each item (behaviour) was rated on a scale from one (never or almost never $=1$ ) to nine (always or almost always $=9$ ), i.e. nine different response alternatives.

The leadership style Developmental leadership has three components: 1) "exemplary model", which includes the indexes for the subcategories "value base", "good example", and "responsibility", each of which are based on three items; 2) "individualized consideration", which includes "support", based on five items, and "confront", based on three items; and 3) "inspiration and motivation", which includes "promote participation", based on four items and "promote creativity", based on three items. The indexes for subcategories have between 27 (three items multiplied with nine response alternatives) and $45(5 * 9)$ unique values. The overarching index for developmental leadership is based on a total of 24 items (216 unique values).

The Conventional leadership has two components ("demand and reward" and "control") with two subcategories each. Three out of four subcategories are based on three items and one subcategory on four items ( 27 or 36 unique values). This means that conventional leadership totally is based on 13 items (117 unique values).

Non-leadership includes only on one index (sub-factor), "Laissezfaire leadership", based on four items (36 unique values).

Five indexes of leadership characteristics/desired competencies are analysed, based on between three and six items.
All indexes are created as means of the included items, i.e. ranging from one to nine. The indexes were only based on observations with information in all items.

\section{Data analysis}

Our dependent variables are leadership behaviours, desirable competencies, and summarized leadership styles. As described above these variables have between 27 and 216 unique values. We analyse how leaders assess their own leadership and how the subordinates assess the leadership of their leader. All analyses were done separately for leaders and subordinates. As an initial step, we examined the distribution of all the dependent variables. The differences between nursing homes and home help services were analysed using linear regression, initially with nursing homes vs home help services as the only independent variable. For assessment of subordinates, we also analysed the differences between nursing homes and home help services controlling for sex, age (divided into categories: $<30$, $30-50$, and $>50$ years). As a result of the relatively small number of participants we also performed a Kruskal-Wallis equality-ofpopulations rank test with the intention to analyse if there were any significant differences in median values between nursing homes and home help services.

We used SPSS version 19.0 for the analyses.

\section{Ethical considerations}

The study was approved by the Ethical Committee in Jönköping, Sweden, DNR: 13-3.

\section{Results}

\section{Differences between leaders' ratings of their leader- ship}

We first investigated whether there were any differences between leaders' self-assessments in nursing homes and home help services. (Table 2) summarizes the results of the leaders' self-assessments.

Table 2 Leaders' self-assessments in nursing homes and home help services

\begin{tabular}{|c|c|c|c|c|c|c|}
\hline \multirow[b]{2}{*}{ Leadership behaviour } & \multirow{2}{*}{$\begin{array}{l}\begin{array}{l}\text { Nursing } \\
(n=I I)\end{array} \\
M(S D)\end{array}$} & \multirow{2}{*}{ homes } & \multicolumn{4}{|c|}{ Home help services $(n=10)$} \\
\hline & & & $M \quad(S D)$ & diff & $\mathbf{p}^{\prime}$ & $\mathbf{p}^{2}$ \\
\hline \multicolumn{7}{|c|}{ Leadership behaviours that are a component of developmental leadership } \\
\hline Value base & $7.39(1.61)$ & & A6.80 (0.83) & 0.59 & 0.310 & 0.114 \\
\hline Good example & $7.55(0.79)$ & & $6.94(0.60)$ & 0.61 & $0.063 \dagger$ & $0.079+$ \\
\hline Responsibility & $7.58(1.18)$ & & $7.24(0.62)$ & 0.34 & 0.425 & 0,161 \\
\hline Support & $7.21(1.05)$ & & $6.50(0.81)$ & 0.71 & $0.099 \dagger$ & $0.040^{*}$ \\
\hline Confrontation & $6.94(1.57)$ & & $6.27(1.11)$ & 0.67 & 0.275 & 0.162 \\
\hline Promote participation & $7.1 \mathrm{I}(0.85)$ & & $7.70(0.70)$ & -0.59 & 0.101 & 0.122 \\
\hline Promote creativity & $7.42(0.90)$ & & $6.47(0.83)$ & 0.96 & $0.021 *$ & $0.023^{*}$ \\
\hline \multicolumn{7}{|c|}{ Leadership behaviours that are a component of conventional leadership } \\
\hline Seek agreements & $7.12(1.35)$ & & $6.33(0.83)$ & 0.79 & 0.129 & 0.122 \\
\hline If, but only if, reward & $3.55(I .83)$ & & $3.80(1.44)$ & -0.25 & 0.738 & 0.973 \\
\hline Take necessary measures & $7.7(0.95)$ & & $7.20(0.88)$ & 0.50 & 0.229 & 0.208 \\
\hline Not over controlling & $8.05(0.80)$ & & $7.35(1.55)$ & 0.70 & 0.205 & 0.428 \\
\hline
\end{tabular}


Table continued...

\begin{tabular}{|c|c|c|c|c|c|}
\hline & $\begin{array}{l}\text { Nursing homes } \\
(n=I I)\end{array}$ & Home help services $(n=10)$ & & & \\
\hline \multicolumn{6}{|l|}{ Desirable competencies } \\
\hline Task-related competence & $6.45(1.40)$ & $5.69(0.62)$ & 0.76 & 0.133 & 0.222 \\
\hline Management-related competence & $7.24(0.89)$ & $8.13(0.7 I)$ & -0.89 & $0.022 *$ & $0.030 *$ \\
\hline Social competence & $5.45(0.82)$ & $5.86(1.06)$ & -0.41 & 0.138 & 0.174 \\
\hline Capacity to cope with stress & $6.50(0.79)$ & $7.63(0.75)$ & -1.13 & $0.003 * *$ & $0.005^{* *}$ \\
\hline Results of leadership & $7.50(1.01)$ & $6.62(0.7 I)$ & 0.88 & $0.034 *$ & $0.040 *$ \\
\hline \multicolumn{6}{|l|}{ Summarized leadership styles } \\
\hline Developmental leadership & $7.3(0.88)$ & $7.95(0.55)$ & -0.65 & $0.059 \dagger$ & $0.050 *$ \\
\hline Conventional leadership & $6.70(0.57)$ & $7.21(0.60)$ & -0.51 & $0.062 \dagger$ & 0.142 \\
\hline Not laissez-faire & $7.48(2.11)$ & $6.98(1.29)$ & 0.50 & 0.527 & 0.917 \\
\hline
\end{tabular}

Note. $* * p<0.01, \quad * p<0.05, \quad \dagger p<0.10$. Results from linear leadership. It is also important to note that leaders' self-rating of 9 of regression $^{1}$ and Kruskal-Wallis equality-of-population rank test ${ }^{2}$. Each dependent variable is rated on a scale from one (never, almost never $=1$ ) to nine (always or almost always $=9$ ). The original values for not overcontrolling and laissez-faire were reversed (never, almost never $=9$ and always or almost always $=1$ ) and the items are now called "not overcontrolling" and "not laissez-faire". Diff. = Mean differences between leaders in nursing homes and leaders in home help services.

Leaders in nursing homes rated themselves statistically significantly higher than did leaders in home help services with regard to the following items: "promote creativity" and "results of leadership", but lower in "management-related competence" and "capacity to cope with stress" (Table 2). Leaders in nursing homes also rated themselves higher than did leaders in home help services $(p$ for mean $<0.10$ ) with regard to "good example" and "support". "Promote creativity", "good example", and "support" are components of the developmental

11 leadership behaviours in nursing homes than in home help services on the DLQ. Leaders in nursing homes rated themselves lower than did leaders in home help services with regard to two "Summarized leadership styles". These results, significant at the 10\% level, indicated that "developmental leadership" and "conventional leadership" were less common in nursing homes than in home help services. The results from linear regression showed one difference between nursing homes and home help services ("conventional leadership") where there was no significant difference in mean.

\section{Differences between subordinates' ratings of their leaders}

We next investigated whether there were any differences between subordinates' assessments of leadership in nursing homes and home help services. Table 3 summarizes the results of subordinates' assessments of their leaders.

Table 3 Subordinates' views of their leaders

\begin{tabular}{|c|c|c|c|c|c|c|c|c|c|}
\hline & $\begin{array}{l}\text { Nurs } \\
(n=4\end{array}$ & omes & $\begin{array}{l}\text { Hon } \\
(n=4\end{array}$ & ervices & & & $\begin{array}{l}\text { Controlled } \\
\text { Model I }\end{array}$ & & \\
\hline Leadership behavior & M & (SD) & M & (SD) & diff & $\mathbf{p}^{\prime}$ & $\boldsymbol{\beta}$ & $\mathbf{p}$ & $\mathbf{p}^{2}$ \\
\hline \multicolumn{10}{|c|}{ Leadership behaviors that are a component of developmental leadership } \\
\hline Value base & 7.30 & $(1.50)$ & 7.10 & $(1.32)$ & 0.20 & 0.945 & 0.11 & 0.663 & 0.755 \\
\hline Good example & 7.38 & $(1.34)$ & 7.45 & $(1.38)$ & -0.07 & 0.815 & 0.17 & 0.512 & 0.778 \\
\hline Responsibility & 7.70 & $(1.30)$ & 8.08 & $(1.52)$ & -0.38 & 0.190 & 0.36 & 0.211 & 0.131 \\
\hline Support & 6.86 & $(\mathrm{I} .40)$ & 6.59 & $(1.57)$ & 0.27 & 0.384 & -0.28 & 0.348 & 0.212 \\
\hline Confrontation & 6.15 & $(2.04)$ & 6.00 & $(1.94)$ & 0.15 & 0.718 & -0.22 & 0.600 & 0.913 \\
\hline Promote participation & 6.74 & $(1.65)$ & 6.62 & $(1.47)$ & 0.12 & 0.717 & -0.21 & 0.518 & 0.929 \\
\hline Promote creativity & 6.57 & $(1.64)$ & 6.55 & $(1.77)$ & 0.02 & 0.962 & -0.016 & 0.648 & 0.833 \\
\hline \multicolumn{10}{|c|}{ Leadership behaviors that are a component of conventional leadership } \\
\hline Seek agreements & 6.82 & $(1.64)$ & 6.78 & $(1.29)$ & 0.04 & 0.889 & -0.11 & 0.725 & 0.772 \\
\hline If, but only if, reward & 3.11 & $(2.01)$ & 2.86 & $(2.06)$ & 0.25 & 0.56 & -0.19 & 0.682 & 0.579 \\
\hline Take necessary measures & 7.02 & $(1.67)$ & 7.06 & $(1.47)$ & -0.04 & 0.915 & 0.00 & 0.991 & 0.590 \\
\hline Not over controlling & 6.88 & $(2.05)$ & 7.64 & $(1.80)$ & -0.76 & 0.061 & -0.97 & 0.018 & 0.045 \\
\hline \multicolumn{10}{|l|}{ Desirable competencies } \\
\hline Task-related competence & 6.24 & $(1.90)$ & 5.87 & (l.79) & 0.37 & 0.331 & -0.47 & 0.229 & 0.316 \\
\hline
\end{tabular}


Table continued....

\begin{tabular}{|c|c|c|c|c|c|c|c|c|c|}
\hline Management-related & \multicolumn{2}{|c|}{ Nursing homes } & \multicolumn{4}{|c|}{ Home help services } & \multicolumn{3}{|c|}{ Controlled } \\
\hline Competence & 7.40 & $(\mathrm{l} .43)$ & 7.83 & $(1.79)$ & -0.43 & 0.160 & 0.28 & 0.355 & 0.098 \\
\hline Social competence & $5.4 I$ & $(1.35)$ & 5.47 & $(1.06)$ & -0.06 & 0.753 & -0.02 & 0.907 & 0.001 \\
\hline \multicolumn{10}{|l|}{ Capacity to cope with } \\
\hline Stress & 5.66 & (I.39) & 5.70 & $(1.56)$ & -0.04 & 0.893 & 0.00 & 0.993 & 0.890 \\
\hline Results of leadership & 6.84 & $(1.55)$ & 6.49 & $(\mathrm{I} .3 \mathrm{I})$ & 0.35 & 0.238 & -0.37 & 0.210 & 0.381 \\
\hline \multicolumn{10}{|c|}{ Summarized leadership styles } \\
\hline Developmental leadership & 6.93 & $(1.22)$ & 6.87 & $(\mathrm{I} .40)$ & 0.06 & 0.834 & -0.08 & 0.748 & 0.785 \\
\hline Conventional leadership & 6.23 & $(1.03)$ & 6.08 & $(1.09)$ & 0.15 & 0.485 & -0.25 & 0.262 & 0.424 \\
\hline Not laissez-faire & 7.67 & $(1.97)$ & 7.35 & $(1.80)$ & 0.32 & 0.418 & $-0.4 I$ & 0.311 & 0.461 \\
\hline
\end{tabular}

Note. ${ }^{*} p<0.05, \uparrow p<0.10$. Results from linear regression ${ }^{1}$ and Kruskal-Wallis equality-of-population rank test ${ }^{2}$. Each dependent variable was rated on a scale from one (never, almost never $=1$ ) to nine (always or almost always $=9$ ). The original values for not overcontrolling and laissez-faire were reversed (never, almost never $=9$ and always or almost always $=1$ ) and the items are now called "not overcontrolling" and "not laissez-faire. Diff. $=\beta$ - coefficient from linear regression correspond to mean differences between leaders in nursing homes and leaders in home help services. The regression models were controlled for sex and age $(<30,30-50$, and $>50$ years). ${ }^{3}$ One median difference was significant when the mean difference was not significant. The median for social competence were 7.0 for nursing homes and 8.1 for home help services $(p=0.001)$.

The results (Table 3) showed that subordinates in nursing homes gave the leadership behaviour "not overcontrolling" lower scores than did subordinates in home help services ( $p$ mean $=0.061$; median $=0.045$ ). After controlling for age and sex the difference was significant ( $p$ for mean $=0.018$ in model 1 ). This means that the leaders in nursing homes were more often seen as over controlling. It is also important to note that subordinates in nursing homes assessed their leaders more positively than did subordinates in home help services with regard to 7 of 11 leadership behaviours. The results from KruskalWallis test of median differences showed one significant difference between nursing homes and home help services (social competence) where there was no significant difference in mean. The mean values were nearly the same, but the median value for nursing homes was 8.1 and 7.0 for home help services $(p=0.001)$.

\section{Discussion}

We first examined differences between the self-assessments of leaders in nursing homes and home help services. The selfassessments of leaders in home help services were significantly lower (less positive) than the self-assessments of leaders in nursing homes with regard to the leadership behaviours "promote creativity", "results of leadership", "good example" and "support". These results may suggest that physical distance between leaders and subordinates in home help services may decrease the opportunities for leaders to get feedback and interact with subordinates. This interpretation is, to some extent, supported by the work of ${ }^{10}$ who found that when a leader works in close proximity to subordinates, he or she is more likely to get instant feedback, whereas when a leader works at a greater distance from subordinates, his or her behaviour is more likely to go undetected.
The developmental leadership model is based on the transformational leadership model. According to, ${ }^{21}$ transformational leaders in social services create a climate that inspires people to communicate and make improvements and that gives them the opportunities to take initiatives that contribute to employee wellbeing in social services.

When leaders and subordinates work near each other, leaders can more easily support subordinates' efforts, and the actions and behaviours of leaders can more easily inspire subordinates. Research has demonstrated close associations between transformational leadership and subordinates' working conditions, including a higher degree of involvement, influence, and meaningfulness, ${ }^{23}$ job satisfaction and well-being in health care professionals' work; ${ }^{22}$ and workplace performance among long-term care professionals, including higher work satisfaction and lower turnover intention. ${ }^{21}$

"Management-related competence" and "capacity to cope with stress" were assessed significantly lower (less positive) by leaders in nursing homes than leaders in home help services. The results may also suggest that when leaders work at a greater distance from subordinates, they need be able to handle stressful situations and show management-related competence due to span of management control in home help services. For example, distance between individuals who need home help services, the number of assignments, and aid needs can all change quickly. The absence of opportunities to directly observe, monitor, and get feedback from subordinates in daily work might impact home help service leaders' assessments of desirable competencies ("management-related competence" and "capacity to cope with stress"). The leaders in nursing homes have these problems to a smaller extent. The number of residents in a nursing home is roughly constant. The residents are located in the same area, although their needs vary, and leaders get direct feedback from subordinates about the leaders' desirable competencies ("results of leadership"). This interpretation is supported by the work of, ${ }^{9}$ and by ${ }^{10}$ who reported significantly higher performance from subordinates with a direct rather than indirect leadership. Leaders' self-assessments in nursing homes might also be more influenced by close interactions with subordinates, than leaders in do in home help services. Because of the close interaction with subordinates leaders might judge their desirable competences less positive.

The leadership styles assessed in the DLQ are based on several items that rate developmental leadership, conventional leadership, and non-leadership. The developmental leadership style is considered 
the most favourable of the three. ${ }^{13}$ The leaders' self-assessments indicate that developmental leadership and conventional leadership was somewhat more common in home help services than in nursing homes. The physical distance between leaders and their immediate followers might have an impact on the opportunity to conduct developmental leadership in home help services.

We then examined differences between subordinates' assessment of leaders' behaviours and characteristics in nursing homes and home help services. It is important to study subordinates' views of their leaders because leadership is the result of subordinates' perception of leaders' behaviour, characteristics, and performance. ${ }^{24}$ In general, there were few differences between nursing homes and home help services. It is noteworthy that the assessment of leader characteristics in nursing homes and home help services was roughly equivalent. The "not overcontrolling" score was significant higher in home help services than in nursing homes after controlling for sex and age. This means that the subordinates in nursing homes more often assess their leaders as overcontrolling. This result may be due to the way work is structured in the two eldercare settings and the lower possibilities for interaction between subordinates and leaders in home help. The leaders in home help services do not have the possibilities to be overcontrolling. There is an advantage for both nursing homes and home help services if they apply the developmental leadership model (e.g. transformational leadership). We do not have any measures on subordinates' assessments on their psychosocial work environment. However, developmental leadership will, according to previous research, increase subordinates satisfaction with their work situation; ${ }^{25}$ create a higher degree of involvement, influence, and meaningfulness of work:;3 and job satisfaction including subordinates well-being. ${ }^{22}$

According to the subordinates' evaluations of leadership styles, there were no significant differences between nursing homes and home help services.

There are also some significant differences in how leaders in home help services vs nursing homes assess their own leadership, but no differences (except overcontrolling) in how subordinates assess their own leaders. This could be because leaders are more dependent on feedback from their subordinates than subordinates are on feedback from their leaders - subordinates might get support and feedback from colleagues to a larger extent than the leaders do.

\section{Limitations}

This study is based on a relatively small number of participants who were selected from one municipality in southern Sweden. This might have an impact on the generalizability of the results.

Each leader distributed the questionnaires to five subordinates. It is possible that leaders choose subordinates they knew well and that this might lead to a more positive assessment of the leaders. However, if there was a bias, the bias would likely be similar in both settings (i.e., nursing homes and home help services). Another limitation that might have affected the results regarding subordinates' evaluations of their leaders was that employees in each work unit might tend to judge the leadership similarly, and this would lead to smaller variation within than between units. This limitation would only affect the results of the analyses of subordinates' questionnaires, not the results of the leaders' questionnaires, since there is only one leader per unit.

Research has shown that leaders in social services must cope with increasingly stringent requirements for cost efficiency and with greater administrative responsibility. ${ }^{5}$ This increasing burden might have negatively affected the view of their leadership. We do not expect this factor to have affected the differences between nursing homes and home help services because the burden has increased in both settings.

\section{Conclusion}

Subordinates in nursing homes seem to feel more controlled and observed (more overcontrolled) in their daily work than subordinates in home help services. The indirect leadership in home help services has the opposite problem, namely a lack of interaction and instant feedback between leaders and subordinates.

Our findings suggest that the social service should recognize the differences in the way nursing homes and home help services are organized and should recruit leaders with traits and behaviours desirable to each eldercare setting. Some aspects of conducting "good" leadership seem to be better met in home help services, some in nursing homes. According to the leaders' self-assessments, leaders were less successful in "good examples", "supportive", and "promote creativity" in home help services. It is therefore essential for municipalities to provide support for leaders, especially in home help services, to develop these behaviours. Leaders in home help services are also less likely to see the results of their leadership. This makes it important to develop ways for them to monitor the results of their leadership, maybe new systems for the subordinates to report the ongoing work. Leaders in nursing homes report lower "managementrelated competence" and "capacity to cope with stress. Therefore, it is important for the organization to create the right support and conditions for these leaders.

\section{Acknowledgements}

None.

\section{Conflict of interest}

Authors declare there is no conflict of interest in publishing the article.

\section{References}

1. Brennan D, Cass B, Himmelweit S, et al. The marketisation of care: Rationales and consequences in Nordic and liberal care regimes. Journal of European Social Policy. 2012;22(4):377-391.

2. Davidson-Perlmutter F, Bailey D, Angelis J, et al. Att styra och leda äldreomsorg. Hur går det till och vad kan förbättras? [To govern and manage the eldercare. How does it work and what can be improved, Sweden; 2014

3. Angelis J, Jordahl H. Att styra och leda äldreomsorg. Hur går det till och vad kan förbättras? [To govern and manage the eldercare. How does it work and what can be improved, Sweden; 2014.

4. Holmberg I. Var finns ledarskapet i offentligt sektor? Where is the leadership in the public sector? In: Holmberg, I, Henning R, editors. Public leadership - about change, renewal and new ideals of leadership. Sweden; 2003. p. 7-29.

5. Antonsson H. Chefers arbete $i$ äldreomsorgen - att hantera den svårhanterliga Omvärlden. Relationen mellan arbete och organisering. Managers work in elder care-to manage the unmanageable: The relation between work and organising. Linköping studies in art and sciences, Dissertation, Liu-tryck, USA; 2013.

6. Avalio BJ, Zhu W, Bhatia P. Transformational leadership and organizational commitment: mediating role of psychological empowerment and moderating role of structural distance. Journal of Organizational Behavior. 2004;25(8):951-968. 
7. Szebehely M, Trydegård GB. Home care for older people in Sweden: a universal model in transition. Health Soc Care Community. 2011;20(3):300-309.

8. Ernsth Bravell M, Malmberg B, Berg S. Functional Capacity, Formal Care and Survival in the Oldest Old? A Longitudinal Study Among the Oldest Old. Arch Gerontol Geriatr. 2008;46(1):1-14.

9. Samia L, Hall Ellenbecker C, Haig Friedman D, et al. Home care nurses' experience of job stress and considerations for the work environment. Home Health Care Services Quarterly. 2012;31(3):243-265.

10. Jane M Howell, Derrick J, Neufeld, et al. Examining the relationship and physical distance with business unit performance. The Leadership Quarterly. 2005;16(2):273-285.

11. Burns J. Leadership. Harper and Row, New York, USA; 1978.

12. Bass BM. Leadership and Performance Beyond Expectations. Free Press, New York, USA; 1985.

13. Larsson G. Ledarskapsteori [Theories of Leadership]. In: Larsson G, Kallenberg K, editors. Direct leadership, Värnamo: Fälth and Hässler, 2003. p. 29-51.

14. Larsson G, Eid J. "An idea paper on leadership theory integration", Management Research Review. 2012;35(3):177-191

15. Larsson G. The Development Leadership Questionnaire (DLQ) Some psychometric properties. Scandinavian Journal of Psychology. 2006;47(4):253-262.

16. Zander A, Nerman L. Developmental leadership. Swedish National Defence College. Departement of Leadership and Management, Sweden; 2010 .

17. Larsson G, Carlstedt L, Andersson J, et al. A comprehensive system for leader evaluation and development. Leadership and Organization Development Journal. 2003;24(1):16-25.

18. Bass BM. Two decades of research and development in transformational leadership. European Journal of Work and Organizational Psychology. 1999;8(1):9-32.

19. Walter F, Bruch H. Structural impacts on the occurrence and effectiveness of transformational leadership: An empirical study at the organizational level of analysis. The Leadership Quarterly. 2010;21(5):765-782.

20. Lee D. The Role of Transformational Leadership Styles in the Home Health Care Industry. Home Health Care Management \& Practice. 2012;24(4):169-174.
21. Tafvelin S, Armelius K, Westerberg K. Toward Understanding the Direct and Indirect Effects of Tranformational Leadership on Well-Being: A Longitudinal Study. Journal of Leadership \& Organizational Studies. 2011;18(4):480-492.

22. Nielsen K, Yarker J, Randall R, et al. The mediating effects of team and self-efficacy on the relationship between transformational leadership, and job satisfaction and psychosocial well-being in healthcare professionals: A cross-sectional questionnaire survey. International Journal of Nursing Studies. 2009;46(9):1236-1244.

23. Nielsen K1, Yarker J, Brenner SO, et al. The importance of transformational leadership style for the well-being of employees working with older people. J Adv Nurs. 2008;63(5):465-475.

24. Antonakis J, Atwater L. Leader distance: a review and proposed theory. The Leadership Quarterly. 2002;13(6):673-704.

25. Braun S, Peus C, Weisweiler S, et al. Transformational leadership, job satisfaction, and team performance: A multilevel mediation model of trust. The Leadership Quarterly. 2013;24(1):270-283.

26. Taly Dvir, Dov Eden, Bruce J, et al. Impact of transformational leadership on follower development and performance: a field experiment. Academy of Management Journal. 2002;45(4):735-744.

27. By Howell, Jane M, Hall-Merenda, et al. The Ties That Bind. The Impact of Leader-Member Exchange, Transformational and Transactional Leadership, and Distance on Predicting Follower Performance. Journal of Applied Psychology. 1999;84(5):680-694.

28. Lawler J. Leadership in Social Work: A Case of Caveat Emptor. The British Journal of Social Work. 2007;37(1):123-141.

29. McCormick EJ, Ilgen DR. Industrial and organizational psychology. Allen and Unwin, London; 1985.

30. Nielsen K, Cleal B. Under which conditions do middle managers exhibit transformational leadership behaviors? - An experience sampling method study on the predictors of transformational leadership behaviors. The Leadership Quarterly. 2011;22(2):344-352.

31. National Board of Health and Welfare. Påverkar chefens personalansvar kvaliteten nom vården och omsorgen? [Do the managers responsibility for staff impact the quality in health and social care], Sweden; 2006.

32. Swedish Research Council. Forskningsetiska principer inom humanistisk-samhällsvetenskaplig forskning. Research ethics principles in humanistic-social science research, Sweden; 1990 